\title{
The Problems of Accounting Reporting False Information and Estimation
} Jeffrey $\mathrm{E}$ Jarrett*

Management Science and Finance, University of Rhode Island, 7 Lippit Road, Kingston, RI 02881, USA

\begin{abstract}
The purpose is to review the development of estimation theory in accounting and to show how it affects a certain principle involved with account for events that do not exchange cash or cash equivalents. The purpose is to give support that earnings and rate of return manipulations not based in accounting principle explain much of the manipulation of earnings and income reports as well as the valuation of assets.
\end{abstract}

Keywords: Estimation problem in accounting; Matching and realization; Recognition; Conservatism

\section{Introduction}

The difficulty with financial reporting statement is the notion that cash flows and non-cash activity are the data source for these reports whether they be income statements, tax reporting statements, cost accounting statements and position statements of assets and equities general known as balance sheets. Financial reporting is extremely important when one analyzes these statements to ascertain the financial stability, wealth and return on equities. Research taught us that the allocation problem in accounting is an application of Estimation Theory first developed in accounting literature by Brief [1] and later extending to the matching and realization principle in accounting by Jarrett [2]. Barnea and Sadan [3] further suggested a decomposition scheme for the estimation problem in accounting. Their purpose was to improve predictability on a firm's rate of return and allow investors to have better information to analyze the reporting statement of firms. In turn, this would clarify problems with estimation of the "true" rate of return on financial assets experienced by firms.

Additional problems in predicting financial rate of return include Bierman [4] who attempted to argue against the application of pricelevel adjustments to the depreciated cost of an asset. Such action would distort the previous investment decisions made by others as to the true value of assets and increase the amount of depreciation taken resulting in biased estimators of the rate of return. Furthermore, Jarrett [5] concluded that the adjustment of book values biases estimates of the rates of return whether they are for a period or overall. Furthermore, using price level adjustments based on indexes not related to the change in prices of assets increases the bias and is directly opposite of the principal of accounting to be "conservative" in accounting when evaluating cost or market prices of assets.

The restructuring of accounting principles enabled one create a new emphasis in accounting to focus the jointness of costs and revenues over time. We no longer emphasize a particular or significant point in time for matching (or recognizing) coasts and revenues prior to the collection and distribution of cash, the emphasis shifted to the overall rate of return. Last, Jarrett finally stated that the overall rate of return may not have a uniform model and in particular may vary according another model which may bring different. These other models may include one with skewness and/ or be an exact model following another exact mathematical model [6].

\section{Assessment of Estimates from Accounting Reports}

To determine if a firm's financial reporting includes earning's estimates that previously manipulated for whatever purpose Beneish
[7-12] produced evidence that accounting principles were violated and/or altered with purpose of manipulating earnings estimates. Their purpose varied from influence rate of return estimates used by external investors and their recommendations by financial earnings estimators and "Wall Street Mavens" to retaining corporate executives from the CEO down. We do not argue that the results of these activities are always detrimental only that they exist and can have negative effects on the Macroeconomy. Billio et al. [13] concluded that monthly returns of hedge funds, banks, broker/dealers and insurance companies affected levels of systematic risk. In particular, banks played a significant role in transmitted shocks to the macroeconomic system during the 2007-2009 financial crisis in the United States and many parts of the "Western World." These shocks contributed to earning manipulations to reduce the magnitude of systematic risk and enable. Earlier, Pappas [14] did dispute the Brief-Owen logic and later refinements as fallacious since the statistical properties of the rate of return does not provide the most pertinent information for investment purposes. However, this did not stop accountants from reporting rates of return for investment purposes.

Crowther [15] stated that and evaluated a framework which recognizes the contexts within which performance evaluation is operating. Integral to this are: the context of control and the role of accounting in the recording and shaping of performance; the context of reporting and the dimensions of accountability within which the business is operating; and the context of planning and a concern for the future orientation of strategic management." His analysis was somewhat related to Jarrett [16,17] whereby the results of those studies indicated that a firm's rate of return estimated by accounting information is dependent on criteria for ranking investment proposals. For imperfect capital markets, estimates of the internal rate of return for a firm are, in turn, related to the scheme for ranking investment proposals. Thus, whether the capital asset pricing model is utilized or other techniques evaluating performance of a firm.

This leads to the implementation of "conservatism" in accounting.

*Corresponding author: Jarrett EJ, Professor, Management Science and Finance University of Rhode Island, 45 Upper College Rd, Kingston, RI 02881, USA, Tel: +401 (874) 4169; Fax: 401 (874) 4312; E-mail: jejarrett133@gmail.com

Received October 14, 2016; Accepted November 07, 2016; Published November 15, 2016

Citation: Jarrett JE (2016) The Problems of Accounting Reporting False Information and Estimation. Intel Prop Rights. S1: 007. doi: 10.4172/2375-4516.S1-007

Copyright: @ 2016 Jarrett JE. This is an open-access article distributed under the terms of the Creative Commons Attribution License, which permits unrestricted use, distribution, and reproduction in any medium, provided the original author and source are credited. 
Filip, and Paugam [18], indicated that the principle of conservatism is a policy of anticipating possible future losses but not future gains resulting in understatements of income and the valuation of assets. This author can remember his Intermediate Accounting Professor (Robert Dixon, University of Michigan) emphasizing this rule almost every day in class and stating that what he taught may not be useful to his students when they became accounting professional. Manipulating of asset valuation by using a price index to estimate again the value of assets or using inventory evaluation rules such as LIFO (last in first out) affect the value of investments and most likely the misstatement of earning and rates of return. Further, Conservatism plays an important role in a number of accounting rules, including the allowance for doubtful accounts and the lower of cost or market. The conservatism principle is the foundation for the lower of cost or market rule, which states that you should record inventory at the lower of acquisition cost or current market value. This conservatism rule is consistent with the matching and realization rules and all other applications in the estimation problem in accounting. We should note that tax authorities in the United States and other nations may argue against this for a variety of reasons not relating to accounting principles [19]

\section{Conclusion}

Rules of financial accounting reporting change when new knowledge of accounting principle change due to new discoveries in accounting research. The evidence generates from studies of which only a number are cited here indicating for a variety of reasons earning and rate of return manipulations exist in both interim and yearly financial statements. The reasons for manipulation are obvious and widespread and they affect, in turn, decisions made in financial reports. Regardless of decision criteria utilized in producing financial reports, often these reports violate long established reporting rules by practioner's of accounting. I do not argue that rules should be set by some legal authority; however, there must be a set of rules which should be followed by all. If they do not, the suggestions by Beneish of using multiple regression models to account for the manipulation should be followed.

\section{References}

1. Jarrett JE (1970) A Note on Earnings Risk and the Coefficient of Variation: Comment. Journal of Finance 25: 1159-1160.
2. Jarrett JE (1971) The Principles of Matching and Realization as Estimation Problems. Journal of Accounting Research 9: 378-382.

3. Barnea A, Sadan S (1974) On the Decomposition of the Estimation Problem in Financial Accounting. Journal of Accounting Research 12: 197-203.

4. Bierman Jr H (1971) Discounted Cash Flows, Price Level Adjustments and Expectations. The Accounting Review 693-99.

5. Jarrett JE (1974) Bias in Adjusting Asset values for Changes in the Price Level: An Application of Estimation Theory. Journal of Accounting Research 12: 63-66.

6. Beneish MD (1999) The Detection of Earnings Manipulation. Financial Analysts Journal 55: 24-36.

7. Beneish MD (1999) Incentives and Penalties Related to Earnings Overstatements That Violate GAAP," The Accounting Review 4: 425-457.

8. Beneish, MD, Lee CMC, Nichols DC (2013) Earnings Manipulation and Expected Returns. Financial Analysts Journal 69: 57-82.

9. Beneish MD, Lee CMC, Nichols DC (2015) In short supply: Equity Overvaluation and short selling. Journal of Accounting and Economics 60: 33-57.

10. Beneish, MD, Marshall CD, Yang J (2016) Explaining CEO Retention in Misreporting Firms," Journal of Financial Economics 1: 1-58.

11. Brief R, Owen J (1969) A Note on Earnings Risk and the Coefficient of Variation," Journal of Finance 24: 901-904.

12. Brief R, Owen $J(1970)$ The Estimation Problem in Financial Accounting Journal of Accounting Research 8: 167-177.

13. Billio M, Getmansky M, Lo AW, Pelizzon L (2012) Econometric measures of connectedness and systemic risk in the finance and insurance sectors. Journal of Financial Economics 104: 535-559.

14. Crowther D (1996) From the foundations upwards: Evaluating business performance', Managerial Auditing Journal 11: 35-47.

15. Jarrett JE (1972) Notes of the Estimation Problem in Financial Accounting Journal of Accounting Research 10: 108-112.

16. Jarrett JE (1983) The Rate of Return from Interim Financial Reports and Journal of Business Finance and Accounting 10: 289-294.

17. Jarrett JE (1973) An Abandonment Decision Model. Engineering Economist 19: $35-46$.

18. Paugam F (2013) Impact of Mandatory IFRS Adoption on Conditional Conservatism in Europe. ESSEC Working Papers WP1311, ESSEC Research Center, ESSEC Business School. SSRN: 1979748.

19. Roberts C, Roberts E (1970) Exact Determination of Earnings Risk by the Coefficient of Variation, Journal of Finance 25: 1161-1165. 